\title{
Ten-year estimated risk of bone fracture in women with differentiated thyroid cancer under TSH-suppressive levothyroxine therapy
}

\author{
Szacunkowe dziesięcioletnie ryzyko złamania kości u kobiet ze zróżnicowanym \\ rakiem tarczycy stosujących terapię lewotyroksyną w celu supresji TSH
}

\author{
Lara Vera', Stefano Gay ${ }^{1}$, Claudia Campomenosi', Sabrina Paolino², Giorgia Pera ${ }^{1}$, Eleonora Monti ${ }^{1}$, \\ Lorenzo Mortara ${ }^{1}$, Bruno Seriolo ${ }^{2}$, Massimo Giusti ${ }^{1}$
}

${ }^{1}$ Endocrine Unit, Department of Internal Medicine, University of Genoa, Genoa, Italy

${ }^{2}$ Research Laboratory and Academic Division of Clinical Rheumatology, Department of Internal Medicine, University of Genoa, Genoa, Italy

\begin{abstract}
Introduction: After thyroidectomy and radioiodine therapy, patients with differentiated thyroid cancer (DTC) are indefinitely treated with levothyroxine (L-T4). Osteoporosis is a debated consequence of hypothyroxinaemia. The aim of this study was to evaluate bone mineral density (BMD) and fracture risk assessed by FRAX in a cohort of DTC women.

Material and methods. Seventy-four women with DTC (aged $56.5 \pm 9.9$ years) treated at the mean age of $51.9 \pm 12.0$ years were studied. Baseline BMD and FRAX were evaluated after 3.0 years (median). BMD and FRAX were further evaluated 5.5 years (median) after the baseline evaluation. A cohort of 120 euthyroid women, matched for age, BMI, and menopausal status, were evaluated as controls.

Results: L-T4 dosages were $813.6 \pm 208.8 \mu \mathrm{g} /$ week and $782.1 \pm 184.4 \mu \mathrm{g} /$ week at the baseline and second evaluation, respectively. The risks of major osteoporotic fracture (MOF) and hip fracture (HF) were similar in DTC patients and in controls. In DTC women, significant changes in FRAX were found, with a higher increase in the probability of HF than of MOF. A similar change was found in controls. A significant inverse correlation $(\mathrm{P}<0.001)$ between L-T4 dosage and HF/MOF probability on both first and second evaluations was found. A significant inverse correlation $(\mathrm{P}=0.05)$ was found between $\mathrm{fT} 4$, TSH and duration of therapy and HF/MOF probability only on the second evaluation.

Conclusions: FRAX increase is a multi-factorial, age-related phenomenon. The absence of correlations between L-T4 dosage, length of therapy or fT4 levels and FRAX does not enable us to attribute an increased fracture risk to DTC women with well-controlled disease on therapy. (Endokrynol Pol 2016; 67 (4): 350-358)
\end{abstract}

Key words: bone fracture risk; osteoporosis; FRAX; thyroid cancer; levothyroxine therapy; hyperthyroxinaemia

\section{Streszczenie}

Wstęp: Chorzy ze zróżnicowanym rakiem tarczycy (DTC) po tyroidektomi i terapii jodem radioaktywnym muszą do końca życia przyjmować lewotyroksynę (L-T4). Jednym z możliwych następstw hypertyroksynemii jest osteoporoza. Badanie przeprowadzono w celu oceny gęstości mineralnej kości (BMD) oraz ryzyka złamania na podstawie wskaźnika FRAX w kohorcie kobiet chorych na DTC.

Materiał i metody: Badaniem objęto 74 kobiety z DTC ( w wieku 56,5 $\pm 9,9$ roku) poddane leczeniu w wieku 51,9 $\pm 12,0$ lat. Wartości BMD i wskaźnika FRAX oceniono na początku badania oraz po upływie 3,0 lat (mediana). Następnie ponownie zbadano BMD i wskaźniki FRAX 5,5 roku (mediana) po początkowej ocenie. Grupę kontrolną stanowiła kohorta 120 kobiet z prawidłową czynnością tarczycy dobranych pod względem wieku, wskaźnika BMI i występowania menopauzy.

Wyniki: Dawki L-T4 wynosiły 813,6 \pm 208,8 $\mu$ g/tydzień i 782,1 \pm 184,4 $\mu \mathrm{g}$ /tydzień odpowiednio na początku badania i w trakcie drugiej oceny chorych. Ryzyko poważnego złamania osteoporotycznego (MOF) oraz złamania bliższego odcinka kości udowej (HF) było podobne $\mathrm{u}$ chorych z DTC i w grupie kontrolnej. U kobiet z DTC stwierdzono istotne zmiany wartości wskaźnika FRAX, przy czym wzrost wskaźnika był większy w przypadku prawdopodobieństwa HF niż u osób zagrożonych MOF. Podobne zmiany stwierdzono w grupie kontrolnej. Zaobserwowano istotną odwrotną korelację $(\mathrm{p}<0,001)$ między dawką L-T4 a prawdopodobieństwem HF/MOF zarówno przy pierwszej, jak i drugiej ocenie chorych. Natomiast istotną odwrotną korelację $(p=0,05)$ między dawką fT4, stężeniem TSH i czasem trwania terapii a prawdopodobieństwem HF/MOF stwierdzono tylko w czasie drugiej wizyty.

Wnioski: Zwiększenie wartości wskaźnika FRAX jest związane z wiekiem i zależy od wielu czynników. Brak korelacji między dawką L-T4, czasem trwania terapii lub stężeniem fT4 a wartością wskaźnika FRAX wskazuje, że nie należy przypisywać zwiększonego ryzyka złamań pacjentkom z DTC, u których uzyskano dobre wyrównanie choroby za pomocą terapii. (Endokrynol Pol 2016; 67 (4): 350-358)

Słowa kluczowe: ryzyko złamania kości; osteoporoza; FRAX; rak tarczycy; leczenie lewotyroksyną; hipertyroksynemia 


\section{Introduction}

Differentiated thyroid cancer (DTC) is an increasingly prevalent malignancy [1]. After thyroidectomy and postoperative radioiodine (RAI) therapy when necessary, patients are indefinitely treated with levothyroxine (L-T4) to suppress thyrotropin (TSH) because inhibiting this stimulating hormone is effective in reducing tumour recurrence rates [2]. The generally favourable prognosis of DTC allows patients to live a long life in a condition of exogenous subclinical hyperthyroxinaemia $[1,3]$.

Osteoporosis is a debated consequence of hyperthyroxinaemia, and the effect of thyroid function on fracture risk (FR) is not clear [4]. Indeed, although biologically active TSH-receptors have been found in human osteoblasts [5], the role of thyroid hormones in the pathogenesis of osteoporosis remains uncertain6. While L-T4 is not associated with an increased FR or osteoporosis in either males or pre-menopausal women $[4,7]$, findings in post-menopausal women are controversial [4].

There is, however, no consensus regarding the importance of various prognostic tools for risk assessment. Bone mineral density (BMD) is one of the main factors predictive of fractures, but a number of independent risk factors may provide additional information on the 10-year FR (10-YFR) [8]. The WHO Collaborating Centre for Metabolic Bone Disease has recently ascertained that the 10-YFR can be estimated by means of the FR assessment tool (FRAX) score, which also includes clinical data and BMD measured by means of dual-energy X-ray absorptiometry (DXA) [8].

The aim of this controlled study was to evaluate BMD and FRAX in a cohort of DTC women. Two assessments were made in order to study changes in BMD and FRAX over time in relation to hormonal data, therapy, and disease evolution.

\section{Material and methods}

\section{Subjects}

We evaluated 74 DTC women (stage 1-4, baseline age $56.5 \pm 9.9$ years, median 56 years; range $40-80$ years) treated at the mean age of $51.9 \pm 12.0$ years. Among all DTC patients followed up in our Endocrine Unit, we select only female DTC subject with two or more bone densitometry examinations. Except for four Hispanic and two Asian women, all were Italian. In 95\% of subjects, the initial therapy consisted of thyroidectomy; this was followed by one or more cycles of RAI in $73 \%$. Histology was papillary thyroid carcinoma (PTC), follicular variant of PTC, and follicular thyroid carcinoma in 63,10 , and 1 subject/s, respectively. All DTC subjects were on L-T4 at the time of the study. L-T4 was started 78 months (median; range 12-229 months) before thyroidectomy for goitre in $11 \%$ of patients. Before thyroidectomy, none of them had been treated with high L-T4 dosage (Table I).

A cohort of 120 euthyroid women, of similar age (baseline age $58.6 \pm 9.9$ years, median 57 years, range 40-80 years), post-menopausal status, body mass index (BMI), and risk factors was evaluated as a control group (Table I). These patients were selected among all patients referred to the Rheumatology Clinic to undergo MOC DXA. Twenty-four women with Hashimoto's disease were on L-T4 substitutive therapy on baseline evaluation. Another two women began L-T4 between the first and the second evaluations.

\section{Study design}

Clinical examination comprised history, evaluation of current therapies, physical examination, and neck ultrasonography (NUS). Baseline BMD and FRAX, calculated on femoral neck BMD, were evaluated 3.0 years (median) after DTC diagnosis. BMD and FRAX evaluations were repeated after 5.0 years (median). Data on thyroid hormones, parathyroid hormone (PTH), serum calcium (S-Ca), and 25hydroxy-vitaminD (25OH-D) were available in all subjects. Thyroglobulin $(\mathrm{Tg})$ and anti-Tg-antibodies (TgAb) were evaluable in all DTC patients.

\section{Laboratory evaluations}

Serum TSH, free-triiodothyronine, and free-thyroxine (fT4) were routinely measured by means of chemiluminescence immunoassay (RocheDiagnostics, Mannheim, Germany). Thyroglobulin was assayed by means of sensitive (until 2013; functional sensitivity $0.5 \mu \mathrm{g} / \mathrm{L}$ ) and ultra-sensitive (functional sensitivity $0.1 \mu \mathrm{g} / \mathrm{L}$ ) chemiluminescence immunoassay (Roche Diagnostics). In healthy subjects without goitre, normal $\mathrm{Tg}$ is $1.5 \sim 78.0 \mu \mathrm{g} / \mathrm{L}$. Thyroglobulin $\mathrm{Ab}$ were evaluated by means of the DiaSorin assay (Saluggia, Italy); a TgAb $<100 \mathrm{mU} / \mathrm{L}$ was regarded as negative. PTH was analysed by means of two chemiluminescence immunoassays (Immunolite2000, Diagnostic Products, San Juan Capistrano, CA, USA until 2010; subsequently, LIAISON N-tact PTH, DIASorin, Saluggia, Italy). Reproducibility of the data yielded by the two methods was excellent. Serum-Ca was determined by means of fully automatic equipment (ModularP800, Roche Diagnostics). Evaluation of $25 \mathrm{OH}$-D was performed by means of a chemiluminescence method (LIAISON, DIASorin).

\section{Imaging}

Neck ultrasound (AU5 Idea and MyLabFive; Esaote, Genoa, Italy) was performed by means of a device 
Table I. Principal epidemiological data, clinical data, and data on treatment effects in the study population (on $1^{\text {st }}$ and $2^{\text {nd }}$ evaluations). Data are expressed as mean $\pm S D$ or percentage unless otherwise specified, with medians in brackets. Significance was taken as $P<0.05$

Tabela I. Najważniejsze dane epidemiologiczne, kliniczne i dotyczq̨ce efektów leczenia w badanej populacji (pierwsza i druga wizyta kontrolna). Dane przedstawiono jako średnie \pm SD lub wartości procentowe z medianq w nawiasach, o ile nie zaznaczono inaczej. Wartości $p<0,05$ przyjęto jako istotne statystycznie

\begin{tabular}{|c|c|c|c|c|c|c|}
\hline \multirow[t]{2}{*}{ Parameter } & \multicolumn{3}{|c|}{ DTC patients $(\mathrm{n}=74)$} & \multicolumn{3}{|c|}{ Controls (n = 120) } \\
\hline & Baseline & $2^{\text {nd }}$ evaluation & P valuea & Baseline & $2^{\text {nd }}$ evaluation & $P$ valuea \\
\hline BMI $\left[\mathrm{kg} / \mathrm{m}^{2}\right]$ & $26.0 \pm 5.3$ & $26.1 \pm 5.0$ & NS & $24.5 \pm 4.2$ & $24.7 \pm 4.2$ & NS \\
\hline Weight [kg] & $68.4 \pm 15.7(65.0)$ & $66.1 \pm 12.6(64.0)$ & NS & $63.5 \pm 10.9(63.0)$ & $63.8 \pm 10.8(63.0)$ & NS \\
\hline Menopausal state (\%) & $78(n=58)$ & $85(n=63)$ & NS & $73.3(n=88)$ & $79.2(n=95)$ & NS \\
\hline Smoking (\%) & $15(n=11)$ & $16(n=12)$ & NS & $8(n=10)$ & $7.5(\mathrm{n}=9)$ & NS \\
\hline Disease-free for DTC recurrence (\%) & $99(n=73)$ & $99(n=73)$ & NS & - & - & - \\
\hline Subject with diseases involving bone $(\%)^{\mathrm{b}}$ & $19(n=14)$ & $22(n=16)$ & NS & $23.3(n=28)$ & $23.3(n=28)$ & NS \\
\hline Calcium/vitamin D supplementation (\%) & $24(n=18)$ & $62(n=46)$ & $P<0.0001$ & $25.8(n=31)$ & $47.5(n=57)$ & $P<0.0005$ \\
\hline Anti-resorptive therapy (\%) & $22(n=16)$ & $32(n=24)$ & NS & $20.8(n=25)$ & $35(n=42)$ & $P<0.01$ \\
\hline Time on L-T4 (months) & $70.9 \pm 70.7(48)$ & $140.7 \pm 115.8(124)$ & $P<0.0001$ & - & - & - \\
\hline L-T4 dosages $[\mu \mathrm{g} /$ week $]$ & $\begin{array}{c}813.6 \pm 208.8 \\
(1.73 \pm 0.42 \mu \mathrm{gxkg})\end{array}$ & $\begin{array}{c}782.1 \pm 184.4 \\
(1.78 \pm 0.40 \mu \mathrm{gxkg})\end{array}$ & $P=0.1$ & - & - & - \\
\hline Cases of fracture $(\%)$ & $7(n=5)$ & $12(n=9)$ & NS & $4(n=5)$ & $5(n=6)$ & NS \\
\hline
\end{tabular}

aBaseline vs. follow-up; bprimary hyperparathyroidism, thyrotoxicosis, malabsorption, rheumatoid arthritis, and other autoimmune diseases; DTC — differentiated thyroid cancer; SD — standard deviation; BMI — body mass index; DTC — differentiated thyroid cancer; L-T4 — levohyroxine; NS — not significant

equipped with a linear 7.5-10 $\mathrm{MHz}$ linear transducer of $60 \mathrm{~mm}$ probe length. BMD in the lumbar spine and hip was measured by means of DXA using Hologic (QDR1500/DQR4500, Bedford, MA) and Lunar Prodigy instruments. The precision of BMD measurements is guaranteed by Phantom measurement, a quality control tool for cross-calibration used before every examination by the same operator. The coefficient of variation (CV) was $0.5 \%$. The least-significant change (LSC) was $2 \%$ and $2.8 \%$ for lumbar and hip BMD, respectively. Conversion equations from Hologic to GE-Lunar systems were used ${ }^{9}$. Using BMD data from two different apparatus does not create a bias; indeed, as the type of instrument can be specified, FRAX takes into account these possible differences, thereby rendering all data comparable.

\section{Survey measurements}

FRAX has been used to calculate the 10-year probability (expressed as a percentage) of $\mathrm{HF} / \mathrm{MOF}$ in subjects aged from 40 to 90 years. All FR factors included in FRAX (age, BMI, previous fracture, parental history of hip fracture, glucocorticoid therapy, smoking, alcohol intake, rheumatoid arthritis, and secondary causes of osteoporosis) were assessed, together with hip BMD data. FRAX was calculated on country-specific (Italy) data by means of a web version of computer-driven 3.8 software.

\section{Statistical analysis}

The best index of DTC cure was taken to be an undetectable baseline or stimulated $\mathrm{Tg}$ with negative $\mathrm{TgAb}$, together with a negative NUS at least one year after ablative therapy. Data were analysed by means of Prism 6.0 software (GraphPad Software, San Diego, CA, USA). All values quoted are mean \pm SD or median (range), unless otherwise specified. Correlation analyses between variables were carried out by means of statistical nonparametric tests, while the Chi-square test was used to compare percentage data. Significance was taken as $\mathrm{P}<0.05$.

\section{Results}

\section{Clinical data}

We evaluated 194 women: 74 DTC patients and $120 \mathrm{eu}-$ thyroid controls. Adiposity was a more frequent finding in DTC subjects than in controls $(\mathrm{P}<0.05)$, owing to the significantly greater number of DTC subjects with substantially stable BMI over $26 \mathrm{~kg} / \mathrm{m}^{2}$ (DTC $44.6 \%$, controls $32 \%$; $\mathrm{P}=0.1$ ). Statistically significant differences emerged only in data on supplemental calcium/vitamin $\mathrm{D}$ treatment. The L-T4 dosage in DTC patients did not change significantly over time (Table I). In patients with bone fractures, most fractures occurred at minor sites (ribs, wrist, foot); only one of the DTC patients had 
Table II. Principal hormonal, biochemical, and bone metabolism data in the study population (on $1^{\text {st }}$ and $2^{\text {nd }}$ evaluation). Data are expressed as mean $\pm S D$ unless otherwise specified or percentage, with medians in brackets. Significance was taken as $P<0.05$

Tabela II. Najważniejsze dane hormonalne, biochemiczne i dotyczące metabolizmu kostnego w badanej populacji (pierwsza i druga wizyta kontrolna). Dane przedstawiono jako średnie \pm SD lub jako wartości procentowe $z$ medianq w nawiasach, o ile nie zaznaczono inaczej. Wartości $p<0,05$ przyjęto jako istotne statystycznie

\begin{tabular}{|c|c|c|c|c|c|c|}
\hline \multirow[t]{2}{*}{ Parameter } & \multicolumn{3}{|c|}{ DTC patients $(n=74)$} & \multicolumn{3}{|c|}{ Controls $(n=120)$} \\
\hline & Baseline & $2^{\text {nd }}$ evaluation & P valuea & Baseline & $2^{\text {nd }}$ evaluation & $P$ valuea \\
\hline TSH [n.v. $0.3 \sim 4.2 \mathrm{mlU} / \mathrm{L}$ ] & $0.66 \pm 1.22(0.16)$ & $0.23 \pm 0.32(0.07)$ & $P<0.001$ & $1.72 \pm 1.91(1.16)$ & $1.91 \pm 1.66(1.4)$ & NS \\
\hline fT4 [n.v. $12.0 \sim 22.0 \mathrm{pmol} / \mathrm{L}$ ] & $20.50 \pm 3.50(20.7)$ & $20.60 \pm 3.30(20.6)$ & NS & $18.20 \pm 2.90(18.4)$ & $17.60 \pm 5.00(18.4)$ & NS \\
\hline S-Ca [n.v. $2.1 \sim 2.7 \mathrm{mmol} / \mathrm{L}]$ & $2.40 \pm 0.17$ & $2.37 \pm 0.12$ & NS & $2.40 \pm 0.15$ & $2.40 \pm 0.12$ & NS \\
\hline $250 \mathrm{HD}$ [n.v. $>30 \mathrm{nmol} / \mathrm{L}]$ & $31.60 \pm 36.50$ & $19.70 \pm 11.80$ & NS & $28.80 \pm 25.60$ & $24.90 \pm 9.40$ & NS \\
\hline BMD lumbar spine $\left[\mathrm{g} / \mathrm{cm}^{2}\right]$ & $1.080 \pm 0.199(1.060)$ & $1.051 \pm 0.200(1.014)$ & NS & $0.842 \pm 0.145(0.831)$ & $0.835 \pm 0.143(0.809)$ & NS \\
\hline BMD hip $\left[\mathrm{g} / \mathrm{cm}^{2}\right]$ & $0.792 \pm 0.131(0.781)$ & $0.771 \pm 0.111(0.751)$ & NS & $0.981 \pm 0.171(0.982)$ & $0.972 \pm 0.173(0.956)$ & $P<0.05$ \\
\hline FRAX HF (\%) & $1.2 \pm 2.0(0.6)$ & $1.9 \pm 3.2(1.1)$ & $P<0.0001$ & $1.7 \pm 2.5(0.8)$ & $2.4 \pm 3.7(1.1)$ & $P<0.0001$ \\
\hline FRAX MOF (\%) & $5.0 \pm 4.1(3.9)$ & $6.8 \pm 6.3(5.3)$ & $P<0.001$ & $6.2 \pm 4.8(4.7)$ & $7.4 \pm 5.3(5.4)$ & $P<0.0001$ \\
\hline FRAX HF (\%) in fracture pts & $3.5 \pm 3.8(1.9)$ & $4.6 \pm 3.9(2.9)$ & $P<0.05$ & $5.3 \pm 5.0(4.5)$ & $5.3 \pm 3.7(5.0)$ & NS \\
\hline FRAX MOF (\%) in fracture pts & $10.8 \pm 6.8(7.7)$ & $13.9 \pm 6.5(12.0)$ & $P<0.01$ & $14.4 \pm 8.2(13.5)$ & $15.7 \pm 5.4(16.0)$ & NS \\
\hline
\end{tabular}

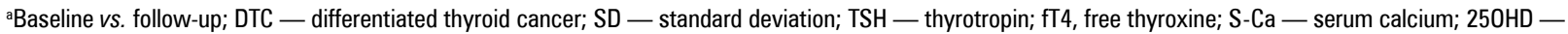
25-hydroxy-vitamin D; BMD — bone mineral density; FRAX — fracture risk assessment tool; HF — hip fracture; MOF — major osteoporotic fracture; n.v. — normal value; NS - not significant

a hip fracture at the first evaluation, while another suffered a vertebral fracture between the first and second evaluations (Table I).

\section{Laboratory data}

As expected, TSH was significantly lower $(\mathrm{P}<0.0001)$ and fT4 was higher (baseline $\mathrm{P}<0.001$; follow-up $\mathrm{P}<0.01$ ) in the L-T4-treated group than in controls at both evaluations. Adequate TSH concentrations under moderate hyperthyroxinaemia in DTC patients were more often observed on follow-up than on baseline evaluation. Serum $\mathrm{Ca}$ and $25 \mathrm{OH}-\mathrm{D}$ showed no differences between DTC patients and controls on both evaluations (Table II).

Serum PTH displayed differences between DTC patients and controls only at the follow-up examination $(\mathrm{P}<0.01)$. Above-normal PTH was observed in $17.6 \%$ of DTC patients and $9.2 \%$ of controls. However, primary hyperparathyroidism was diagnosed in only 5 DTC patients and one control.

Table II shows the main biochemical and hormonal data and a comparison between baseline data and follow-up data within patients and controls separately.

\section{Bone and FR evaluations}

With regard to BMD, DXA results were significantly lower in DTC patients than in controls in the lumbar spine $(\mathrm{P}<0.0001)$ and hip $(\mathrm{P}<0.001)$. No significant changes in lumbar BMD (L2-L4) from baseline to follow-up evaluation were observed in either DTC patients or controls. However, a significant reduction in femoral neck BMD from baseline evaluation to follow-up was observed in controls, but not in DTC patients. The proportion of women in whom osteopaenia/osteoporosis criteria in the femoral neck were normal according to the T-score and WHO criteria did not significantly differ between DTC patients and controls (DTC: $69.6 \%$ at baseline and follow-up evaluations; controls: $67.5 \%$ and $61.7 \%$ at baseline and follow-up). In both groups, osteopaenia was slightly more frequent than osteoporosis, although the difference was not statistically significant. The MOF/HF risks measured by FRAX were similar in DTC patients and controls at both evaluations (Table II). The incidence of new cases of bone fracture was higher in DTC patients, although not significantly (Table I). Among six controls with bone fractures, HF was $>3 \%$ in four and MOF was $>20 \%$ in only one; among nine DTC patients with bone fractures, FRAX HF/MOF was $>3 \%$ and $>20 \%$ in four and two cases, respectively (Table II). In both of these subgroups, HF/MOF values were higher, both at the baseline and at follow-up evaluation, than those recorded in subjects without fractures, but were not significantly different between DTC and controls. Fractures occurred in 14\% of controls and $35 \%$ of DTC with HF $>3 \%$, and in $30 \%$ of controls and $75 \%$ of DTC with MOF $>20 \%$.

Finally, between the first and second evaluations, a percentage variation exceeding the value of LSC was found in $84 \%(\mathrm{~N}=62)$ of DTC patients in lumbar BMD 

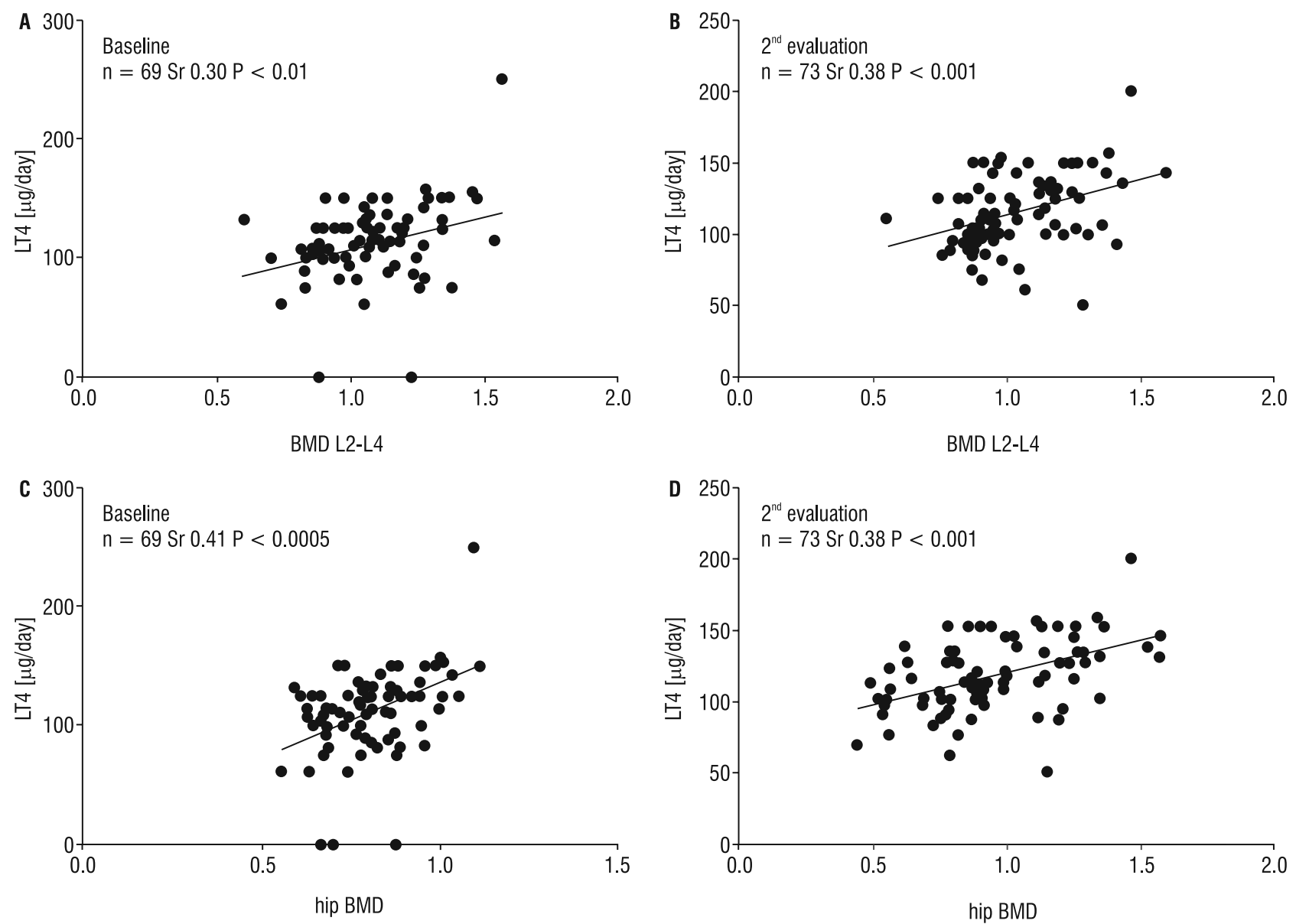

Figure 1. Significant correlation between L-T4 dosage and lumbar and hip BMD, both at the baseline (A, C) and on $2^{\text {nd }}$ evaluation (B, D) in DTC patients

Rycina 1. Istotne korelacje między dawką L-T4 a BMD kręgów i bliższego odcinka kości udowej u chorych z DTC, na początku badania (A, C) oraz w czasie drugiej wizyty kontrolnej (B, D)

and $66 \%(\mathrm{~N}=49)$ in hip BMD, and in $77 \%(\mathrm{~N}=92)$ of controls in lumbar BMD and 63\% (N = 75) in hip BMD.

\section{Correlation analysis}

The increase in TSH in DTC patients from baseline to follow-up was not related to significant changes in lumbar BMD. We did not find any correlation between hip and lumbar BMD and other factors of bone compromission (age, L-T4 dosage, BMI, etc.) in any of the subjects at either evaluation, with the exception of a positive correlation between hip BMD and weight $(\mathrm{P}<0.0001)$. However, menopausal patients had lower values of lumbar and hip BMD than non-menopausal women $(\mathrm{P}<0.05$ in hip and 0.001 in lumbar BMD). The presence of other osteopaenia-inducing diseases did not determine differences in BMD.

A significant direct correlation emerged between the daily L-T4 dosage and hip and lumbar BMD (Fig. 1) and a significant inverse correlation emerged between L-T4 dosage and HF/MOF probability, at both evalua- tions (Fig. 2). This correlation persisted on estimating the correlation of HF/MOF with LT- 4 dose as $\mu \mathrm{g} / \mathrm{kg}$ only at the follow-up evaluation. Moreover, the daily levels of L-T4 were not significantly correlated with age. No correlation was found between $\mathrm{HF} / \mathrm{MOF}$ changes and the length of L-T4, fT4, or TSH. Only in DTC patients at baseline was a correlation found between S-Ca and HF/MOF probability $(\mathrm{P}<0.05)$.

A differentiated analysis of DTC patients on antiresorptive therapy (ART) in comparison with the respective controls and with the naive patients (Tables III and IV) showed that hip BMD was lower in DTC patients, at both evaluations, whereas FRAX did not change; at both evaluations, hip BMD was lower in both DTC patients and controls on ART than in patients who were not on ART; consequently, FRAX was higher in patients on ART, who therefore had a higher FR. No significant change was observed between the first and second evaluation in any of the subgroups examined. 

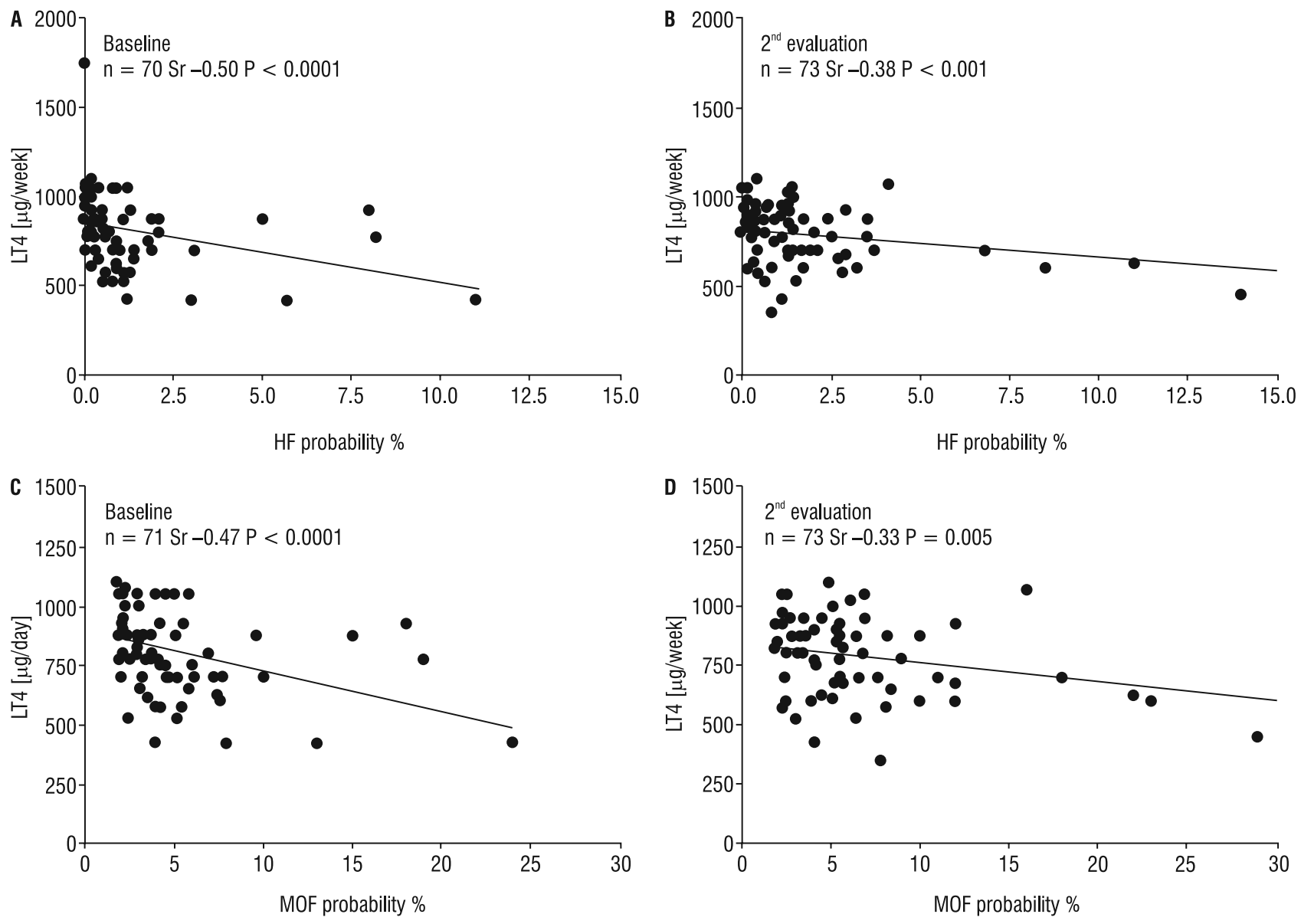

Figure 2. Significant inverse correlation between L-T4 dosage and HF/MOF probability evaluated by FRAX, both at the baseline (A, C) and on $2^{\text {nd }}$ evaluation (B, D) in DTC patients

Rycina 2. Istotna odwrotna korelacja między dawką L-T4 a prawdopodobieństwem HF/MOF ocenionym na podstawie wskaźnika FRAX u chorych z DTC, na poczattku badania (A, C) oraz w czasie drugiej wizyty kontrolnej (B, D)

Table III. Principal bone metabolism data in the study population receiving anti-resorptive treatment (on $1^{\text {st }}$ and $2^{\text {nd }}$ evaluation). Data are expressed as mean $\pm S D$, unless otherwise specified, or percentages

Tabela III. Najważniejsze dane dotyczqce metabolizmu kostnego w badanej populacji stosującej leki antyresorpcyjne (pierwsza i druga wizyta kontrolna). Dane przedstawiono jako średnie \pm SD lub jako wartości procentowe, o ile nie zaznaczono inaczej

\begin{tabular}{|c|c|c|c|c|c|c|c|c|}
\hline \multirow[t]{3}{*}{ Parameter } & \multicolumn{4}{|c|}{ DTC patients } & \multicolumn{4}{|c|}{ Controls } \\
\hline & \multicolumn{2}{|c|}{ With anti-resorptive } & \multicolumn{2}{|c|}{ Without anti-resorptive } & \multicolumn{2}{|c|}{ With anti-resorptive } & \multicolumn{2}{|c|}{ Without anti-resorptive } \\
\hline & $\begin{array}{l}\text { Baseline } \\
(n=13)\end{array}$ & $\begin{array}{c}2^{\text {nd }} \text { evaluation } \\
(n=22)\end{array}$ & $\begin{array}{l}\text { Baseline } \\
(n=60)\end{array}$ & $\begin{array}{c}2^{\text {nd }} \text { evaluation } \\
(n=51)\end{array}$ & $\begin{array}{l}\text { Baseline } \\
(n=25)\end{array}$ & $\begin{array}{c}2^{\text {nd }} \text { evaluation } \\
(n=42)\end{array}$ & $\begin{array}{l}\text { Baseline } \\
(\mathrm{n}=90)\end{array}$ & $\begin{array}{c}2^{\text {nd }} \text { evaluation } \\
(n=78)\end{array}$ \\
\hline $\begin{array}{l}\text { BMD lumbar } \\
{\left[\mathrm{g} / \mathrm{cm}^{2}\right]}\end{array}$ & $0.864 \pm 0.126$ & $0.945 \pm 0.153$ & $1.123 \pm 0.183$ & $1.097 \pm 0.202171$ & $10.905 \pm 0.146$ & $0.862 \pm 0.147$ & $0.826 \pm 0.141$ & $0.817 \pm 0.138$ \\
\hline $\begin{array}{l}\text { BMD hip } \\
{\left[\mathrm{g} / \mathrm{cm}^{2}\right]}\end{array}$ & $0.678 \pm 0.123$ & $0.721 \pm 0.103$ & $0.817 \pm 0.120$ & $0.792 \pm 0.109$ & $0.792 \pm 0.095$ & $0.831 \pm 0.128$ & $1.029 \pm 0.152$ & $1.046 \pm 0.147$ \\
\hline FRAX HF (\%) & $3.45 \pm 3.66$ & $4.05 \pm 4.89$ & $0.73 \pm 0.97$ & $0.70 \pm 0.72$ & $3.14 \pm 2.96$ & $3.93 \pm 3.39$ & $1.39 \pm 2.24$ & $1.61 \pm 3.66$ \\
\hline FRAX MOF (\%) & $9.91 \pm 6.90$ & $11.01 \pm 8.85$ & $3.98 \pm 2.07$ & $4.13 \pm 2.09$ & $8.58 \pm 5.73$ & $10.08 \pm 6.43$ & $5.58 \pm 4.31$ & $5.91 \pm 3.84$ \\
\hline
\end{tabular}

DTC — differentiated thyroid cancer; SD — standard deviation; BMD — bone mineral density; FRAX — fracture risk assessment tool; HF — hip fracture; MOF — major osteoporotic fracture. 
Table IV. A differentiated analysis of DTC patients receiving anti-resorptive treatment in comparison with the respective controls, DTC patients without anti-resorptive treatment and controls without anti-resorptive treatment (on $1^{\text {st }}$ and $2^{\text {nd }}$ evaluation). Significance was taken as $P<0.05$

Tabela IV. Analiza różnicowa chorych na DTC przyjmujących leki o działaniu antyresorpcyjnym w porównaniu $z$ grupq kontrolnq stosująca takie leczenie, chorymi na DTC niestosującymi leczenia antyresorpcyjnego i osobami z grupy kontrolnej niestosującymi leczenia antyresorpcyjnego (pierwsze i drugie badanie kontrolne). Wartości $p<0,05$ przyjęto jako istotne statystycznie

\begin{tabular}{|c|c|c|c|c|c|c|}
\hline \multirow[t]{2}{*}{ Parameter } & \multicolumn{2}{|c|}{$\begin{array}{c}\text { DTC on ART } \\
\text { vs. } \\
\text { Controls on ART }\end{array}$} & \multicolumn{2}{|c|}{$\begin{array}{c}\text { Controls on ART } \\
\text { vs. } \\
\text { Controls without ART }\end{array}$} & \multicolumn{2}{|c|}{$\begin{array}{c}\text { DTC on ART } \\
\text { vs. } \\
\text { DTC without ART }\end{array}$} \\
\hline & Basal & $2^{\text {nd }}$ evaluation & Basal & $2^{\text {nd }}$ evaluation & Basal & $2^{\text {nd }}$ evaluation \\
\hline BMD lumbar spine $\left[\mathrm{g} / \mathrm{cm}^{2}\right]$ & NS & $\mathrm{P}<0.05$ & $\mathrm{P}<0.05$ & NS & $\mathrm{P}<0.0001$ & $P<0.005$ \\
\hline BMD hip $\left[\mathrm{g} / \mathrm{cm}^{2}\right]$ & $P<0.005$ & $P<0.005$ & $P<0.0001$ & $P<0.0001$ & $P<0.0005$ & $P<0.05$ \\
\hline FRAX HF (\%) & $P=N S$ & $P=N S$ & $\mathrm{P}<0.0005$ & $\mathrm{P}<0.0001$ & $P<0.001$ & $P=N S$ \\
\hline FRAX MOF (\%) & $P=N S$ & $P=N S$ & $P<0.005$ & $P<0.0001$ & $P<0.0005$ & $P<0.0001$ \\
\hline
\end{tabular}

DTC — differentiated thyroid cancer; ART — anti-resorptive therapy; BMD — bone mineral density; FRAX — fracture risk assessment tool; HF — hip fracture; MOF — major osteoporotic fracture; NS — not significant

\section{Discussion}

We compared the 10-YEAR in 74 DTC women in exogenous hyperthyroxinaemia and in 120 euthyroid women. DTC is a prevalent malignancy that mainly affects women [1], as does osteoporosis. We therefore selected an exclusively female sample. The distribution of histological diagnoses in DTC patients reflects that reported in the literature [10].

Vitamin D deficiency is common in Italy, particularly in the elderly. This finding is worse in those institutionalised or with other comorbidities because of both low sun exposure and dietary imbalances, together with poor compliance with its therapeutic formulation [11]. The decrease in vitamin $\mathrm{D}$ at the second evaluation in all subjects, despite supplementation, can be explained by its age-related depletion in our patients, as in the general population.

The fractures recorded in both patient groups occurred at the most common sites of osteoporotic fracture observed in the general population. Moreover, a separate analysis of the patients with fractures confirmed the predictive capability of FRAX.

In our opinion, this study is particularly interesting because, although endogenous hyperthyroidism is a risk factor for secondary osteoporosis, the effects of supra-physiological L-T4 dosages on bone are still under discussion [12]. Previous studies have not reported significant changes in BMD among premenopausal women and men [4, 7]. Findings in postmenopausal women have remained unclear4 and need further study. Moreover, there are no literature data on the FR evaluated by means of FRAX in postmenopausal women treated with L-T4 suppressive doses because of DTC [12].

\section{Considerations on FR}

Our data confirmed that, as reported in the literature [13], bone metabolism study and FR evaluation are important in patients on L-T4, when administered at high doses, as in DTC patients. Our data show that the HF risk is higher than the MOF risk and does not seem to be related to either the time on L-T4 or TSH. Conversely, in contrast with the data from some previous studies ${ }^{14}$, in our study, reducing the L-T4 dosage - in order to reduce the risk of disease recurrence and on account of increasing age - was associated with an increased FR, as evaluated by FRAX. While this increased risk seems to be age-related, we cannot exclude the possibility that other factors are involved. These include: 1) lower compliance with ART; 2) disputed TSH action on bone [15], in that its direct positive effect may decline; and 3) changes in age-related cytokine agents which remodel the skeletal characteristics of DTC patients [16]. Moreover, we cannot exclude the possibility that the L-T4 dosage at the first evaluation may be influenced by the manipulations necessary in the initial phases of therapy and staging (RAI, rhTSH-test).

Contrary to what would be expected in the state of pharmacologically induced hyperthyroxinaemia, obesity is frequent in DTC patients [17], and our women were also overweight. It can therefore be hypothesised that the absence of significant deterioration in bone metabolism may be the result of a protective effect against bone mass loss and that this effect is due to the very state of being overweight or to the slowing down of the metabolism [18]. Moreover, our data show that BMD is not influenced by other factors of bone compromission, except for weight and menopausal status.

The absence of a positive correlation between L-T4 dosage, time on L-T4 or fT4 and FRAX does not allow 
us to determine whether or not these patients have an increased FR. However, the data analysed showed that, in women on L-T4 for some time, the FR increases at the same rate as in healthy subjects, regardless of the difference detected on first evaluation. When there is a difference, this does not depend on the time of treatment or reduction in the TSH levels.

Moreover, we can certainly say that the increase in FRAX score is a multifactorial phenomenon closely related to age; indeed, the study showed that BMD in women treated for DTC did not vary, unlike FRAX. This age-related increase in FRAX in the absence of a significant age-related reduction in BMD is to be expected, in that age is one of the main variables used to calculate FRAX. Although our data did not reveal a difference in the fracture probability and incidence of bone fracture between patients on L-T4 suppressive therapy and healthy subjects, it can be said that neither TSH reduction nor the duration of therapy results in an increase in long-term risk.

The negative correlation of L-T4 with the probability of fracture may be distorted, as the value of FRAX increases with advancing age, while the need for L-T4 decreases as metabolic needs change. However, although FRAX is an age-related datum, as already mentioned, the daily L-T4 dosage in our study was not correlated with age, which confirms the significant correlation between FRAX and L-T4. This correlation is in line with the correlation seen between BMD and L-T4 dosage.

Finally, this study confirmed the importance of assessing the 10-YFR by means of FRAX in these patients, as part of the follow-up recommended for their underlying disease [19].

\section{Considerations on FRAX}

FRAX is a valid means of estimating FR both in the general population and in patients with primary osteoporosis. Nevertheless, some considerations on the use of FRAX in DTC subjects should be made. Indeed, this algorithm is based on a finite number of variables, those considered most crucial in influencing FR [20]. However, it cannot consider all the factors involved in this process; indeed, hyperthyroidism itself [8] may be a risk factor, regardless of any other variable used to calculate the FRAX score. In this regard, it must be said that some new methods that include more factors, such as exercise and calcium intake (data not included in our study), are being studied. Moreover, studies on FRAX are constantly being updated and extended (e.g. Derived-FR-Assessment orDeFRA) [20], in ordertomake this instrument as accurate as possible so that it can become a definitive approach to patients at risk of fracture.

\section{Limitations}

The first limitation of this study concerns the age of the patients. Between the first and the second evaluations the mean age rose from 56 to 61years; consequently, the percentage of menopausal patients increased (from $78 \%$ to $85 \%$ ). This could be a confounding factor because the literature reports a strong protective effect of oestrogens on bone; thus, the impoverishing effect of thyroid hormone on bone [21] in pre-menopausal women may have been masked. However, to overcome this limitation, we selected a sample of age-matched controls. The second limitation concerns the presence of conditions and diseases affecting bone metabolism (Table II) in $20 \%$ of DTC patients, and of ART administration in $22 \%$ and $32 \%$ of patients at the first and second evaluations, respectively. However, our control group included the same percentage of patients on ART and with rheumatic diseases or diseases involving bone. Moreover, we performed a differentiated analysis of these patients in comparison with their respective controls and naive patients. The fact that patients on ART had a higher FR than naive patients can probably be ascribed to the fact that subjects who require this therapy are those with lower BMD. Thus, proper application of the therapeutic indications enables the bias to be reduced. Finally, our median follow-up was only five years, while FRAX concerns a period of 10 years. A study conducted over a longer period of observation could therefore yield more significant data.

From a technological point of view, BMD was compared at the hip. Hyperthyroidism mainly affects cortical bone. Therefore, BMD at the radius is the most accurate measure of L-T4-related bone loss. However, wrist assessment was rarely performed in most patients. With regard to lumbar BMD, we measured the BMD of the L2-L4 segment. Extending this assessment to $\mathrm{L} 1$ tends to reduce the total BMD value, in that the BMD of L1 is lower than that of the L2-L4 segment. Moreover, the anatomical variability of L1 and its proximity to the lower ribs are factors that may alter the results. Radiography is a reliable means of evaluating asymptomatic vertebral fractures. However, it was not possible to carry out this exploration to confirm the results in all subjects. Indeed, as spinal X-ray was performed only in the event of painful symptoms, asymptomatic spinal fractures could have been missed.

\section{Conclusions}

FRAX increase seems to be an age-related multi-factorial phenomenon. The absence of positive correlations be- 
tween L-T4 dosage, length of therapy or fT4 and FRAX does not allow us to attribute an increased FR to DTC women with therapeutically well-controlled disease.

\section{References}

1. Reverter JL, Colomè E, Holgado $\mathrm{S}$ et al. Bone mineral density and bone fracture in male patients receiving long-term suppressive levothyroxine treatment for differentiated thyroid carcinoma. Endocrine 2010; 37: $467-472$.

2. Reverter JL, Holgado S, Alonso N et al. Lack of deleterious effect on bone mineral density of long-term thyroxine suppressive therapy for differentiated thyroid carcinoma. Endocr Relat Cancer 2005; 12: 973-981.

3. Pacini F, Schlumberger M, Dralle $\mathrm{H}$ et al. European Thyroid Cancer Taskforce. European consensus for the management of patients with differentiated thyroid carcinoma of the follicular epithelium. Eur J Endocrinol 2006;154: 787-803.

4. Ricken R, Bermpohl F, Schlattmann P et al. Long-term treatment with suprafhysiological doses of thyroid hormone in affective disorders - effects on bone mineral density. J Affective Disorders 2012; 136: e89-e94.

5. Morimura T, Tsunekawa K, Kasahara T et al. Expression of type 2 iodothyronine deiodinase in human osteoblast is stimulated by thyrotropin. Endocrinology 2005; 146: 2077-2084.

6. Heemstra KA, Hamdy NAT, Romijn JA et al. The effects of thyrotropinsuppressive therapy on bone metabolism in patients with well-differentiated thyroid carcinoma. Thyroid 2006; 16: 583-591.

7. Biondi B, Cooper DS. Benefits of thyrotropin suppression versus the risks of adverse effects in differentiated thyroid cancer. Thyroid 2010; 20: 135-146.

8. Polovina S, Popovic V, Duntas L et al. Frax score calculations in postmenopausal women with subclinical hypothyroidism. Hormones 2013; 12: $439-448$.
9. B Fan, Y Lu, H Genant et al. Does standardized BMD still remove differences between Hologic and GE-Lunar state-of-the-art DXA systems? Osteoporos Int 2010; 21: 1227-1236.

10. Rosai J. Poorly differentiated thyroid carcinoma: introduction to the issue, its landmarks, and clinical impact. Endocr Pathol 2004; 15: 293-296.

11. Adami S, Romagnoli E, Carnevale V et al. Guidelines on prevention and treatment of vitamin D deficiency. Reumatismo 2011; 63: 129-47.

12. Tuchendeler $\mathrm{D}$, Bolanowski $M$. The influence of thyroid disfunction on bone metabolism. Thyroid Research 2014; 7: 12. DOI:10.1186/s13044-014-0012-0.

13. Heemstra KA, Hamdy NA, Romijn JA et al. The effects of thyrotropin-suppressive therapy on bone metabolism in patients with well-differentiated thyroid carcinoma. Thyroid 2006; 16: 583-591.

14. Nicholls JJ, Brassill MJ, Williams GR et al. The skeletal consequences of thyrotoxicosis. Journal of Endocrinology 2012; 213: 209-221.

15. Abe E, Marians RC, Yu W et al. TSH is a negative regulator of skeletal remodeling. Cell 2003; 115: 151-162.

16. Giusti M, Cecoli F, Ghiara C et al. Recombinant human thyroid stimulating hormone does not acutely change serum osteoprotegerin and soluble receptor activator of nuclear factor-kappaB ligand in patients under evaluation for differentiated thyroid carcinoma. Hormones 2007; 6: 304-313.

17. Giusti M, Mortara L, Degrandi G et al. Metabolic and cardiovascular risk in patients with a history of differentiated thyroid carcinoma: a case-controlled cohort study. Thyroid Res 2008; 1 : 2.

18. Mpalaris VI, Anagnostis P, Goulis DG et al. Complex association between body weight and fracture risk in postmenopausal women. Obes Rev 2015. DOI:10.1111/obr.12244.

19. Schlumberger M, Berg G, Cohen O et al. Follow-up in low-risk patient with differentiated thyroid carcinoma: a European prospective study. Eur J Endocrinol 2004; 15: 105-112.

20. Adami S, Bertoldo F, Brandi ML et al. Guidelines for the diagnosis, prevention and treatment of osteoporosis. Reumatismo 2009; 61: 125.

21. Schneider DL, Barrett-Connor EL et al. Thyroid hormone use and bone mineral density in elderly women. Effects of estrogen. J Am Med Ass 1994; 271: k1245-1249. 